\title{
Philosophizing the Jobs's iPhone within Philospohical Hermeneutics Context
}

\author{
By Daphne Vidanec
}

\begin{abstract}
Charles Taylor, worldwide known contemporary Canadian thinker holds a stand that people "grasp their life in a narrative". Following his conception of narrative notably explicated within identity discussion context in Charles Taylor's remarkable Sources of the Self: The Making of the Modern Identity (HUP 1989), we might think of a narrative as an unavoidable form that shapes one's private and professional relationships. Especially, the last one is recognizable in the modern world of high-tech and digitally mediated business (and relations). Within these lines the author primarily aiming to establish methodological base for understanding the concept of digital narrative, which is proposed by the master of digital smart technology and an inventor of $i$-Phone (2007): Steve Jobs. The author's thesis is, that, as highlight of 21st c. modern technologies, Steve Jobs's iPhone represents more than a mere 'money-can-buy-product'. With its app(s)designed, a cell phone of a kind as i-Phone certainly is represents an idea of one's personal (digital) identity. In order to show how philosophy can shape human private and professional practice in the digital era, the two philosopher's outlooks will be proposed in the following pages. The author's start-position is that human life sphere in the digital age takes shape through manifold technological influences produced and launched by public and digital media (e. g. TV, Internet, radio, smart-phones, iPads etc.) as well as through other forms of the whole range of high technologies, what has, consequentially, changed human agency and the picture of what personal identity is. This elaboration tends to answer the two: (1) the nature of narrative within one's personal identity shaping by following theoretical positions of the two brilliant thinkers: Charles Taylor and Paul Ricoeur and (2) the meaning of narrated identities within the context of human agency shaped by strong digital communication mediated by i(Phone)technology?
\end{abstract}

\section{Introduction}

\section{Narrated Digital: an iPhone Phenomenon}

When I've started to write this paper under the above-mentioned title, I didn't exactly know where it will lead me until the very end. And, considering a theoretical platform of my investigation of digital narrative or digital identity, I have been changing my mind a couple of times.

First of all, I imagined this elaboration as a discussion about the narrative concept within the context of communicology. But, as it seems that I would deal

"Professor, University of Applied Sciences Zaprešić, Croatia. 
with delicate content, I have decided then to make a shift by replacing the term of communicology with the concept of digital, because my claim is that Jobs's iPhone beyond economic profitability mediated by the trade market in its essence represents a methodological platform for new discipline: Philosophy of Digital. ${ }^{1}$ For digital narrative we might say that is subordinated to communicative moral behavior: a human agency. This subordination is related with methodology of the meaning of the term of digital. ${ }^{2}$ Generally, digital can be applied to the variety of actions specific to technological progress and high technology industry oriented towards multiplication of the systems run by a finger (or a hand); something like "thinking finger" or "thinking hand" $3 \mathrm{~A}$ hand might be seen as a mediator within the process of thinking. In our age in digital space (e. g. Viber, Whatsapp) we communicate via hidden encrypted digital language mediated by a smart phone technology which is usually supported by the Android or iOS system and what depends on smart phone and gadget producer. The word "smart" within the mentioned phrase I use as a synonym for 'thinking hand'. A thinking hand is the hand that moves stimulated by brain activities: reasoning, thinking, perceiving etc, so we might speak of smart phone as of 'revolution of digital thinking' - in pragmatic way the best described in Steve Jobs's iPhone (see Figure 1.)

The body of iPhone is constructed according to human anatomy. Each app performs an action separately and independently from another one and autonomously functions as small multiplied software integrated into the iPhone unit - i. e. app and put on the screen - a display (see figure 2.).

1. Additionally, this elaboration arose from my examinations of $i$ Phone phenomenon within Business Ethics course which I teach since 2009 onwards in the fall semester at undergraduate study program at a higher education institute in Croatia. Those examinations finally came up to the day-light at a conference on business related science held in Venice, Italy in the fall 2018, organized by a college in Ljubljana, Slovenia. At this conference I presented the outcomes of my long-term investigation(s) made in the field of the narrative concept which were concerned more about the role and the place of philosophy of narrative within business context in the field of high-technology and industry of digital gadgets. Humbly I will mention that I was rewarded for the best scientific paper on philosophizing the Jobs' iPhone delivered at the mention conference.

2. This idea I can thank to the great Germanophone philosopher Martin Heidegger and its critique of the outcomes of the technique in the contemporary culture.

3. Martin Heidegger, Was heisst Denken?/What is called Thinking? (Tübingen: Max Niemeyer Verlag, ${ }^{51997) . ~}$ 


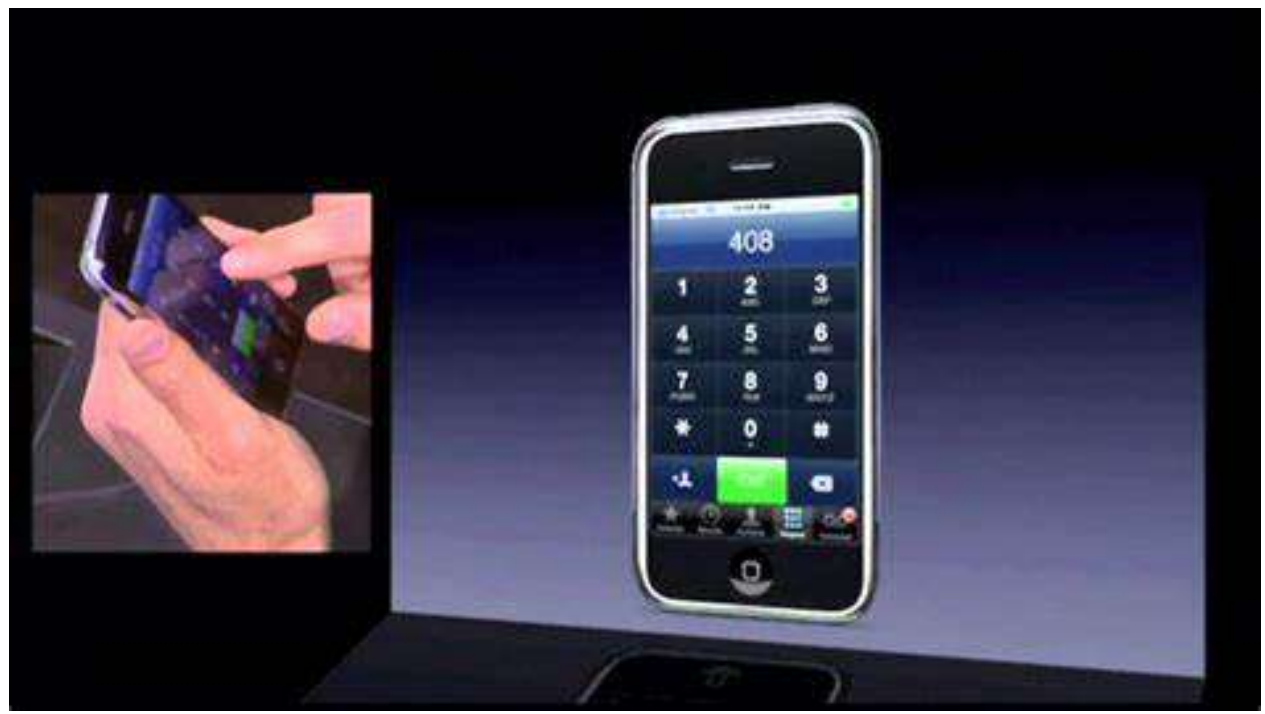

Figure 1. The $1^{\text {st }}$ Generation iPhone

Source: https://binged.it/2IUeqPe.

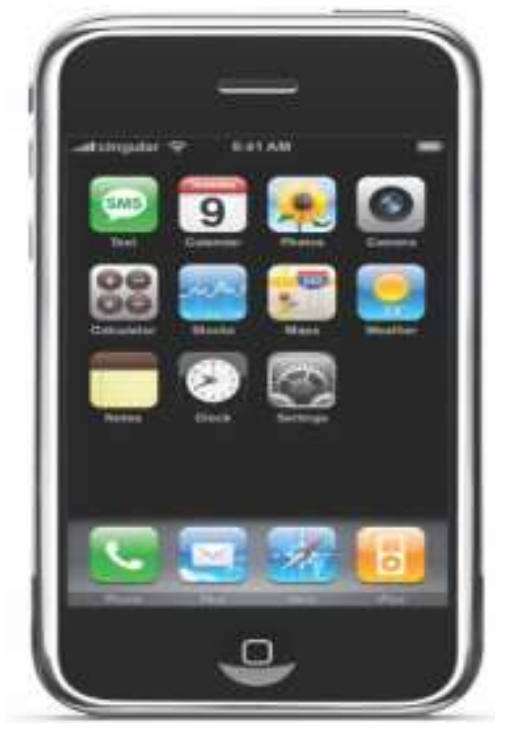

Figure 2. iPhone's 2007 Display

Source: https://bit.ly/2IQRpwi.

As unique body iPhone operates on the same way as central nerve system does within human organism.

The structure of the iPhone apps echoes the structural function of central and vegetative neuro system within human organism. The brain of the iPhone is iOSmemory in specific way connected with external - cyber-space: an iCloud. Something like collective multidimensional memory. And iPhone's cardiovascular system - the heart of this the most sophisticated highly-designed product for wireless communication on a distance is the capacity of the iPhone's battery which supplies whole iPhone's system with (charging in) energy in exact way that 
human heart supplies our body with oxygen via blood-system, in both cases it is the two-phased flux (energy) system. iPhone has eyes: a highly-powered iPhonecamera; ears: user's sounds and loudspeaker(s) and other functions necessary for vital daily activity of a one. In his structure, iPhone represents a digital identity of a man, but in its purpose, it does not enable communication only, but serving as a proof to the progress in sequences of technical sciences pioneered by Nikola Tesla.

Tesla proved that our spatial surrounding - he defined it as 'the Ether ${ }^{\prime \prime}$ is built out of magnetic-electric waves that can be transmitted through entire universe and much far: "(o)nly the existence of a field of force can account for the motions of the bodies as observed, and its assumptions dispenses with space curvature. All literature on this subject is futile and destined to oblivion. So are all attempts to explain the working of the universe without recognizing the existence of the ether and the indispensable function it plays in the phenomena. My second discovery was of a physical truth of the greatest importance. As I have searched the entire scientific records in more than half dozen languages for a long time without finding the last anticipation, I consider myself the original discoverer of this truth, which can be expressed by the statement: There is no energy in matter

4. Though the term might be inappropriate to the contemporary natural scientists, hoping they will excuse me in using the term here, and though the term itself provokes certain scientific ambiguation, I think that Tesla's description of "the Ether" pretty much depicts what philosophers call a metaphysical reality: a wholeness. Scientifically, it can never be (a)proved in a way that is expected to be. I think that Tesla's speculative notion of the Ether, seen from the semantic perspective, is overlapping with Charles Taylor's metaphysical explanation of the concept of "the spatial orientation" widely explicated through the entire concept of his Sources of the Self: The Making of the Modern Identity. In order to explain relation between identity and moral agency Taylor takes an ancient notion of the good and he says that "we have to be rightly placed in relation to the good" in what I call the process of building up our morally shaped reality or, as he says: "the ether of good". - Charles Taylor, Sources of the Self: The Making of the Modern Identity (Cambridge: Harvard University Press, 1989), 44. (The text's emphasis is of author's. In further citation the book will be cited in its shortly version as The Sources: Charles Taylor, Sources (Cambridge: Harvard University Press, 1989, a. n.).

In both cases the ether might refer to a certain environment - weather we speak of it in terms specific to moral philosophy: a dialogical environment (i. e. moral behavior) or to natural science - I will borrow Leibnitz's term of "a macrocosm", is about spatiality - in both case of Charles Taylor and Nikola Tesla, as I stressed earlier. And tracing Taylor's explanation in above mentioned book, "spatial" refers to something that is extensive: I would name it as a "res extensa" - originally coined by René Descartes, when speaking of a substance.

The latest explanation is an offshoot of thinking collected during my specialization in the field of the modern philosophical taught during the summer semester of the second year of my post-diploma - master in science study at the Jesuits' university. 
other than that received from the environment". ${ }^{5}$

The term "digital" is an adjective derived from ancient Latin "digitus"6, a word that refers to a part of a hand: usually the first finger: a forefinger. The term gained its popularity among high-tech industry, computing science and public and academic discourse thanks to Steve Jobs, whose idea was to "reinvent the phone" in 2007. iPhone is revolutionary phone ran by pressing the "pressing button" with a help of forefinger - which is in the latest versions of iPhones technically assimilated into display construction.

My theses I want to investigate here is that communicative zone mediated through digital media i. e. iPhone, iPad, MacBook Air - Apple's touch-screen version of laptop and alike is undoubtedly a question of the understanding the very nature of human language. And I think that we can thank to Steve Jobs for that for the way how human language operates partly (if not entirely, a. n.) has transformed from colloquial into digital expression.

Digital expression is something completely new in our contemporary culture which is nearly a hundred per cent defined by so-called " $\mathrm{I}$ "-technology. Consequentially, $21^{\text {st }} \mathrm{c}$. culture became an environment where everything what we can see and feel is underlined by "the "I-" or "Me-concept", in both living and virtual environment. Let us call this "environment" 7 a narrative space supported by two the most important pillars of the narrative: communication and dialog8 and both are modes of the language structure in general.

Steve Jobs has launched a new methodology of understanding the way of how people can express their (personal) identities and not just via their expressive appearance - rhetoric mime, or the way they speak by using the body language or just the words. Due to the highlights of technological progress and industrial technologies in contemporary culture people can commun(icat)e via and within digital space. My concern here is related with a question: Is digital language which is mediated through different smart phones' apps and alike of mimetic or of story-telling provenience? If we post the answer on the given question relaying on the base of the philosophical hermeneutics proposed by $20^{\text {th }} \mathrm{c}$. German Martin Heidegger, the answer might look as it follows.

Heidegger was-in a way-obsessed with the role of technique and technologies within contemporary culture and the $20^{\text {th }} \mathrm{c}$. philosophical discourse. In his notable

5. Nikola Tesla, "Was Nikola Tesla right about his ether theory?" Physics, https://bit. ly/2YZPFug.

6. Herein I use the term by following an etymology, because I hold a stand that explanations offered by advanced technological science try to redirect the accent from broader - dialectical to narrower - pragmatical.

7. Just for the sake of this investigations and in order not to collide with Tesla's concept of "the Ether" (a. n.).

8. In my opinion, a self-talking or monolog is also a form of dialog - conception already proved by Aurelius Augustine's Confessions (a. n.). 
philosophical writing originally entitled Was Heisst Denken $?^{9}$, when speaking of the role of thinking in the modern age, ${ }^{10}$ he proposes a lucid idea by explaining why human hand is a mediator of the human mind ${ }^{11}$ activities. This mediation we can describe in a following way: what mind performs, a hand (can) make, i. e. can create and produce. ${ }^{12}$

Heideggerian prophetically posed discourse of what I name "a thinking hand" explicated in his previously mentioned writing has found a way towards the notion of the understanding the self-materialization process via digitally structured source - an iPhone.

iPhone is a highlight of the high-tech pioneered by Steve Jobs. Jobs' story of $i$ Phone has undoubtedly found the place within the context of contemporary philosophy and moral discourse, as well as within higher education academic milieu. The first two issues will be discussed through Charles Taylor's and Paul Ricoeur's ambiguations concerning narrative concept widely explicated in their philosophical works on the pages that follow. The latest one I leave for another discussion on that how iPhone changed our life, economy and trade market. ${ }^{13}$

Charles Taylor, contemporary Canadian philosopher pioneered the theory of moral behavior which can only be achieved through communicative ${ }^{14}$ zone: a moral space where the good is taken as "spatial metaphor"15 for everything what we do and who we are or should be(come). The good is a metaphor for one's moral code or an ethics. And the way how we came up to the point where we recognize ourselves as morally shaped creatures has a history and when is about the history, accordingly, we are dealing with the concept of narrative. Narrative is a metaphor for story-telling which has its roots in the modern novel. ${ }^{16}$

Paul Ricoeur, on the other hand, investigates a flux of a story called transition of narrative through the threefold mimetic activities for which he finds terms of

9. Martin Heidegger, Was heisst Denken?/What is called Thinking?. (Cited from Croatian translation of Heidegger's mentioned work published under the title Što se zove mišljenje? (Zagreb: Naklada Breza, 2008, 61-63).

10. Martin Heidegger, What is called Thinking?

11. I use a term of mind because Heidegger speaks of the concept of thinking, not of brain activities in the perspective of neurosciences. Hi is a philosopher. If I may add, in my opinion the best one in 20th c.

12. Martin Heidegger, What is Called Thinking?/Što se zove mišljenje?, 61.

13. The paper about iPhone purchasing management curve is in preparation, at the moment at the first stage: collecting the data on world-wide iPhone purchasing.

14. Tracing Taylor, I use a term as a metaphor for moral or Aristotelian notion of the good. Aristotle, Nicomachean Ethics (Zagreb: Faculty of Political Sciences and Liber University Press, 1980), I., 1094 a 1 - 5.

15. Charles Tayler, Sources, 28. (For the book citation explanation see note 1 in "Introduction" part).

16. Charles Taylor, Sources. 
"mimesis1, mimesis2 and mimesis3". ${ }^{17}$ Ricoeur's three-leveled mimetic activity occurs within certain moral space. Following Taylor and Tesla, let us call it "the ether of good". The very concept is important for further understanding of the moral base of one's personal identity which is according to Taylor determined by temporal dimension. ${ }^{18}$

When speaking of the nature of narrative ${ }^{19}$ both thinkers are agreed with the conception of temporal continuity. If we put the very syntagma of temporality in the context of digital, we deal with the "old-new" concept: "a digital narrative"20. If the narrative concept can be justified by the modern technologies in the field of informatics, computing (science) and digital industry in our age continuously followed by the economic growth and vice versa, how then to explain the nature of digital narrative ${ }^{21}$ Moreover, what creates our life space beyond moral codes, responsibility, and love of money - these are words that describes the nature of our modern age - of "modernity" 22?

\section{Beyond I-Phone Construction}

\section{A Digital-Virtual?}

Popular TV movies or series are telling stories about life we are called upon to follow, e. g. in Nietzschean manner: "the concept of tragic" ${ }^{23}$ of life expressed via soap-operas and alike, but it is fundamentally wrong conception. Movies or series can give us only partial insight into our personal identities of that of what? or who? we really are. An insight into "immanent world" ${ }^{24}$, but what is going on beyond this immanence remains untold.

17. Paul Ricoeur, Time and Narrative: vol. 1 (Chicago and London: The University of Chicago Press, 1983), 52-94.

18. Charles Taylor, Sources, 50.

19. Ibid., 50, 97, 105-106, and 285-302.

20. The phrase is coined by the author in the purposes of this investigation(s).

21. For discussion see: Helen Fulton et al., Narrative and Media (Cambridge: Cambridge University Press, 2005); Robert Scholes, James Phelan and Robert Kellog, The Nature of Narrative (Oxford: Oxford University Press, 2006); Lewis P. Hinchman and Sandra K. Hinchman ed., Memory, Identity, Community. The Idea of Narrative in the Human Sciences (New York: State University of New York Press, 2001); John S. Dunne, Time and Myth (Notre Dame and London: University of Notre dame Press, 1975).

22. Charles Taylor's term.

23. The notion of "tragic" is taken from Friedrich Nietzsche's "Beyond Good and Evil". See: Friedrich Nietzsche, Beyond Good and Evil/S one strane dobra i zla (Beograd: Grafos, 1980).

24. Charles Taylor, A Secular Age (Cambridge and London: The Belknap Press of Harvard University Press, 2007). 
Human life is - let me borrow the phrase from the movie title which was very popular among young generations in early eighties of the $20^{\text {th }}$ century and was sung by British singer known under the name of Limahl: "a never-ending story"; life is "a never-ending story". But, on the other hand, the narrative is designed in a way that always seeking for a certain 'the end-concept' within one's story of life that reflects one's natural tendency towards or after certain closure. And the closure might be 'that' purpose we seek. So, we speak of teleological aspect of narrative concept and the télos we might describe in a term of thánatos.

While delivering commencement speech ${ }^{25}$ to Stanford University graduate students in 2005, Steve Jobs said that thánatos ${ }^{26}$ "is the best single invention of the life". Therefore, we are not able to speak of life without thinking of death. We are not able to discuss about communicative narrative without being aware of fact that the term communicative, whether we speak of sciences or of studies in general or of man, implies both immanence and transcendence within its linguistic structure. Hence, we speak of metaphysically designed narrative within communicative, (i. e.) digital context related to human beings via high-tech.

My object of investigation here is strictly connected with digital narrative ${ }^{27}$ and I have no intention to enter the area of communications studies curricula, because those subjects are not of my concern here and it was already discussed at length before my interference into the very problem ${ }^{28}$ This elaboration also has educational purpose: to show how interdisciplinary approach to the various questions and issues related to the communication studies might look like. And, of course, to show where is the place of moral philosophy within communication studies curricula in great part built on the foundations of technical sciences, economics and modern technologies. I want to clarify the three here: (1) philosophically posted critique on an account of communications and digital media context; (2) I want to show that many features, such as virtual or fictional reality attached to the world of digital technologies might be taken as certain transition of actions within "the mimetic circle" 29 ; (3) the question of understanding the narrative within virtual, i. e. digital world ${ }^{30}$ - the world created by different modes of media: "myth, story, epic, novel, film, soap operas, print media" 31 , and so forth.

25. The speech is widely known as Jobs's famous speech about the meaning of life and death a. n.).

26. Ancient Greek term for death.

27. The term is coined for the purpose of this elaboration and it signifies Jobs's iPhone.

28. William R. Sherman and Alan B. Craig, Understanding Virtual Reality. Interface, Application, and Design (The Morgan Kaufmann Series, 2018).

29. Paul Ricoeur, Time and Narrative: vol. 1., op. cit.

30. I use term of virtual as synonym for fictional.

31. Helen Fulton et al., Narrative and Media, op. cit. 
Narrative theme is a vast area that can be approached from the very different corners: philosophical, semiotics, psychological, linguistic, literary criticism and so forth. The term of narrative is a correlative term and has many meanings. According to its etymology, narrative has its linguistic roots in Latin verb narrare which draws from adjective gnans, in English translation referred to 'knowing' or 'skilled' and from proto-Indo-European root gnō which means 'to know'. In broad sense narrative means a story. As a matter a fact, story is synonym of a narrative. Furthermore, narrative can also be related with what is referring to the sequences of events described in certain narrative i. e. story. This explanation of narrative is very close to Aristotelian theory of plot (of mythos) in his Poetics.

Contemporary experts of narrative theory speak of dozens of terms related to narrative: narrative mode, narration, narrative therapy, narrative environment, narrative film, narrative history, narrative poetry, metanarrative, and, of course, what is the major concern here: a digital identity or digital narrative. We can easily notice that the very term is present in the different disciplines and scientific fields from philosophy, linguistic, art of poetry and history up to psychology, cinematography and ecology. All the abovementioned explanations of narrative, in my opinion, and according to the contexts of their usage are possible to classify in three categories: (1) dialogical: philosophy and communications; (2) chronological: history and literature and (3) methodological: e. g. psychology and other social sciences. All three categories are representing phases of self-interpretation that implies exactly what Ricoeur defines as mimēsis1, mimēsis2 and mimēsis3. On the other hand, we have communication concept as the basic element of the communication(s) science or studies, so we might speak of communication as of multifaceted activity of doing, speaking, producing, distributing, collecting, digitalizing, and activity of sharing. In the aspect concerning epistemological foundations which originally draws roots from Aristotelian zóon politikon axiom modern communications studies (e. g. Communications and Media, Public Relations, Communications Management) are not an invention of contemporary culture or of science. Metaphorically, it is an old song that echoes new rhythm reinforced by high technologies and achievements made in the field of informatics and other technical disciplines embedded in communications studies curricula.

\section{Antithetical Virtual Space from the Ethical Point of View}

If we analyze the term of life from the St Augustinian theoretical perspective and - as Paul Ricoeur proposes in his Time and Narrative - we might claim that life signifies something what is comprehendible only through its temporal metamorphoses known to us as the time-phases of our existence: past, present and future. In the contrast with Augustinian linear view of life- 
time, some contemporary thinkers hold a stand that life concept should be observed as biological process which has its genesis that starts with birth, continues with growing and maturing, and ends up with death. - Of course, there are many objections on an account of positivistic view. In a way, we are indeed caught in the cage constructed by mechanistic - Cartesian outlook which starts and ends up - metaphorically - with worshipping all mighty "disengaged reason" 32 or the idea of immense autonomy of man (e. g. Kant, Nietzsche, Schopenhauer).

In order to pose the communicative narratives issue within philosophical context, ${ }^{33}$ I will take two key-figures who belong to the contemporary history of philosophy and whose names I have already mentioned before, but whose philosophical stances are of great importance for understanding the concept of narrative within contemporary philosophical discourse, but also within communication sciences milieu and social sciences context in general: Charles Taylor and Paul Ricoeur. Let me start with Taylor's analysis of narrative issue because it is related to the concept of "moral behavior"34 i. e. "human agency"35 designated by the picture which public media offers us through different sources of knowledge, and the picture is not so clear and comprehensible, as we might think of it. The picture created and designed by public media metaphorically - is often infected by different, epistemologically designed 'diseases' launched within certain political or economic or academic milieu. Hence, contemporary man in many cases is forced to seek the truth outside the public media area. Sometimes the term 'outside' may refer to that, what is beyond reality: the virtual space of virtual politics, virtual science, virtual education, virtual spirituality, virtual identity etc. ${ }^{36}$ In order to understand the power of virtual we are called upon to investigate our life in reality, because the life which is not investigated, as Socrates said, is not worth of living. In other words, we have to be critical to everything what put our existence into doubt, and virtual world has nothing on Aristotle's or Plato's concept of the virtue itself, because the virtue is shifted from moral - natural i. e. ancient polis-discourse into artificial - digital one. Consequentially, we are dealing with digital as dialogical offshoot of modern technologies and technological progress. Martin Heidegger spoke about it in his Being and Time as of an

32. Charles Taylor, Sources, op. cit.; Charles Taylor, The Ethics of Authenticity (Cambridge and London: Harvard University Press, ${ }^{112003) .}$

33. AAVV, Communication Today, vol. VII., 2 (2016) (Trnava: Faculty of Mass Media Communication - University of SS Cyril and Methodius).

34. More psychological term.

35. Term specific to moral philosophy discussions.

36. More or less, we all experienced what does it mean to be involved with virtual life in the age of COVID - 19: a global medical, economic, social, moral and religious shock with which people around the globe are facing with it since late 2019 and early 2020 . 
existential tool - in Heidegger's language, "ready-to-hand"37 to our "being". From the position offered by vigorous philosophical critique of modernity well-presented in the writings of Charles Taylor, who, in certain way, opposes to those who are thinking of our contemporary culture as of certain moral and spiritual clash only, the very concept of the virtual world created by public media and computing industry cannot be judged differently but through the meaning of the term of artificial one. In that context the term of virtual echoes 'Potemkin's village' illusion. A phrase I use here as a metaphor for administratively designed virtual space of certain society whose purpose is to destruct one's self-attention or a self-awareness. Of course, concerning the natural order of things in the environment ${ }^{38}$ specific to certain society - in order to increase the scope of "atomized society". ${ }^{39}$

Virtual world, let me borrow Heideggerian term, is "a monorail" 40 world where people are used to create "monorail thinking" 41 . And what is the most doubtful in our time is the fact that we don't think, yet. ${ }^{42}$ Virtual world is a world of pure practice and action; it is not mimetic one in ethical, Aristotelian sense. Mimesis involves what refers to morally shaped agency: capacity of morally shaped evaluation of our thoughts, deeds, movements etc. - Aristotelian concept of phrónesis. ${ }^{43}$ Virtual world represents certain aspect of one's agency: a material one which is measurable according to the requests of "instrumental rationality" which is mainly focused on efficiency and calculating the figures. ${ }^{44}$ Explained in the terms of computing science and digital industry: windows, dots, pixels, scores, apps etc., it depends on subject or a matter of discussion, and there is a wide range of subjects discussed within computing and engineering: from designing a new hardware - a deviser for producing and (or) upgrading an old version of some video-game or smart phone software or hardware structure upgraded to the latest one (e. g. iPhone 5, iPhone XS, or iPhone Pro 11 - an iOS). (http://www.apple.com).

Virtual world is created to serve the global economy and the trade market - the gaming industry is quite good example of it with its revenue of $\$ 121 \mathrm{bn}$ in $2019 .{ }^{45}$ That is a story of virtual narrative how I see it from the ethical point of view.

Let us see how its philosophical insight might look like.

37. Martin Heidegger, Being and Time/Bitak i vrijeme (Zagreb: Naprijed, ${ }^{21988), ~ 82-83 . ~}$

38. Herein I use the term in Tesla's manner I have mentioned here under the title "Narrated digital: an iPhone phenomenon".

39. Charles Taylor, The Ethics of Authenticity, op. cit.

40. Martin Heidegger, What is called Thinking?/Što se zove mišljenje?, 65.

41. Ibid.

42. Ibid., 13, 33.

43. Charles Taylor, Sources, 86-87.

44. Charles Taylor, The Ethics of Authenticity, 4-8.

45. VB Transform 2020, https://bit.ly/3bvLzMO accessed 22 April 2020. 


\section{Interpretation as Reflection of Inner-virtual Narrative}

Taylor's central thesis is that "people are self-interpreting animals" 46 capable of "self-evaluation" 47 . Self- or "strong evaluation" is not just the keynotion of Taylor's theory of narrativity and narrative identity, but also a kind of a new methodological approach to the understanding of human life and its meaning: the wholeness of our existence. This idea of self- or strong evaluation is not originally of Charles Taylor's epistemological invention. Its epistemological roots are represented in Harry Frankfurt's thesis in his "Freedom of the will and concept of a person". ${ }^{48}$

According to Frankfurt human beings differ from another earthly living species in their capability of forming "second order desires" 49 . Humans are able to evaluate their desires "to regard some as desirable and others are undesirable." 50 This is why "no animal other than man... appears to have the capacity for reflective self-evaluation that is manifested in the formation of second order desires." ${ }^{51}$

Analyzing Taylor's interpretation of Frankfurt's conception of second order desires, Taylor discovers a problem concerning methodology. He thinks that this mode of agency described in Frankfurt's term of "second-order desires" involves further distinction that Taylor sees as a question of the two kinds of evaluation of desires, namely "weak and strong evaluation". 52 Strong evaluation plays inescapable role in forming narrative identity.

One among the most known commentators of Taylor's philosophical thought, Ruth Abbey thinks that the "strong evaluation and moral frameworks are not only both necessary parts of the structure of human life according to Taylor, but they interact." 53 Abbey shares opinion that Taylor's notion of strong evaluation is sometimes synonim for moral frameworks, as Taylor discusses in the second chapter of his Sources of the Self, that "provide us the background... for our moral judgements, intuitions, or reflections in any of the three

46. Aristotle cited in: Charles Taylor, Human Agency and Language. Philosophical Papers 1 (Cambridge: Cambridge University Press, 1985), chap. 2, especially see 1th $\S$ at the p. 65. 47. Ibid., 66-68.

48. Ibid., 1516, 102; Ruth Abbey, Charles Taylor (Princeton and Oxford: Princeton University Press, 2000), 17-26; Nicholas H. Smith, Charles Taylor. Meaning, Morals and Modernity (Cambridge: Polity Press and Blackwell Publishers Ltd., 2002), 88-92; James Tully (ed.), Philosophy in an Age of Pluralism. The Philosophy of Charles Taylor in Question (Cambridge: Cambridge University Press, 1994), 173-174.

49. Charles Taylor, Human Agency and Language. Philosophical Papers 1, 15-16.

50. Ibid.

51. Ibid.

52. Ibid., 16-18, 29.

53. Ruth Abbey, Charles Taylor, 35. 
dimensions. ${ }^{454}$ And this act of interaction springs out through the different ways of self-interpretation that belongs to the certain social and cultural environment attached to the dialogical aspect of one's identity. Therefore Taylor "believes that individuals necessarily interpret their lives in narrative terms; they make sense of their lives as an unfolding story in a way that gives meaning to their past and direction to their future." 55 This temporal aspect of human existence Taylor poses explicitly by saying that one's "selfunderstanding necessarily has temporal depth and incorporates narrative". ${ }^{56}$ That means "that we understand ourselves inescapably in narrative". ${ }^{57}$

According to Taylor there is a "close connection between the different conditions of identity, or of one's life making sense". ${ }^{58}$ Tracing Taylor, we might say that the best mode is always the one that leads toward understanding the life in narrative form as a 'quest'59. Of course, it is always a quest after what our life makes whole and meaningful, and what plays central role in the stories that individuals construct and reconstruct about their life is a moral good. These stories, as Abbey explains following Taylor, "might include the discovery of a new good, the recovery of an old one, the sudden or dawning realization of an ongoing one, the needs to chose among goods or a period of bewilderment and loss of orientation." ${ }^{60}$. Regarding Taylor's formulation that people grasp their live in a narrative, it is not completely his epistemological invention. ${ }^{61} \mathrm{He}$ cites the work of MacIntyre, Ricoeur and Bruner as well as Heidegger. However, Taylor's claims about the necessary structure of moral life involves orientation towards strongly valued goods, as Abby explicates, grounds the role of narratives more solidly in moral theory. In this sense we might talk of Taylor's contribution to both narrative and moral theory. I think that Taylor takes notion of narrative in order to describe a way in which mutual relations between individuals operate in certain society, culture and space in general. Taylor holds a stand that narratives give

54. Charles Taylor, Sources, 26.

55. Charles Taylor, Sources, 47, 50-52; Ruth Abbey, Charles Taylor, 37-38.

56. Charles Taylor, Sources, 50.

57. Charles Taylor, Sources, 51.

58. Ibid.

59. Taylor has borrowed this term from MacIntyre. See: Charles Taylor, Sources, 48.

60. Ruth Abbey, Charles Taylor, 38.

61. Originally, this formulation belongs to Abbey's observations explicated in her study on Taylor's philosophical taught. But, reading and studying Taylor's philosophical opus I figured out that he is not a creator but re-creator of ideas, themes and problems that are known to us from another philosophical sources. For an instance, when he wants to describe some problem or to express some of his thesis, he often borrows terminology from another thinkers. One who is familiar with Taylor's work knows what I am talking about here, so it is not accidently if my claim coincides with Abbey's one, who is leading Taylor's bibliographer and commentator, but surely not the only one. 
meaning to the histories, present and future of groups in a way that nations tell stories about themselves and within the nation boundaries. Ethnic groups, as well as religion's traditions also develop narratives about their founding and their progress from there. So, as we've seen, narratives have a function on each level of human life: individual, social, political, economic, religious, and cultural. This social aspect of narratives sketched by Taylor reveals ontological pluralism and recognition of the qualitatively different sorts of goods that exist in people's life. ${ }^{62}$ Taylor is convinced that moral theory has to make some contact with a way people experience their moral lives. In this conviction Taylor is showing up to us as a thinker inspired by an Aristotelian outlook. From Aristotle Taylor summed up insight that ethical theory has to be comprehended by the given practice. It means that it just cannot be abstracted from it. ${ }^{63}$. In my opinion, Aristotelian 'the polis-syndrome' 64 is deeply incorporated in Taylor's moral outlook regarding the concept of narrative. ${ }^{65}$

Summing up Taylor's theory on both self-interpretation and self-evaluation we may conclude that narrativity has several functions in forming one's identity: (1) the free choice function: narratives are an optional medium for articulating some of our implicit self-interpretations and strong evaluations. (2) the expressive function: narratives enable us to care about our lives as wholes

62. Ruth Abbey, Charles Taylor, 38.

63. Ruth Abbey, Charles Taylor, 49.

64. This is originally my term which I used in my unpublished paper "'The Ethics of Identity' as a Reaction on 'Challenges' of Globalization" where I speak of conception of modern polis-syndrome. My thesis is that in attempting to explain the real nature of human beings, Aristotle used the term social i. e. political to justify his - in my opinion utopian theory that the purpose of being, living and existing is neither reachable nor possible outside of the boundaries of the civil community - the ancient polis. For Aristotle, human beings are naturally related and connected to the community, but not to any community - to the ideal one: a polis. Aristotle believed that polis is par excellence community of those who share the same life goals - permanent and constant happiness (eudaimonía) understood as final télos. Such happiness could be achieved only under one condition: in active participation in political life of the polis. But, as many modern thinkers have noticed (such as R. Kraut), Aristotle was wrong because his concept of idealistic social life in the eyes off modern man is pure utopia. In some segments Taylor holds Aristotelian position on dialogical character of identity and that position can be formulated as correct incorporation of identity into the self-told story of his or her life. The great proponent of this position, except Taylor, is Alasdair MacIntyre. MacIntyre maintains that "man is in his actions and practice, as well as in his fictions essentially story-telling animal".

65. Alasdaire MacIntyre, After Virtue: A Study in Moral Theory (London: Duckworth, 21985) (Croatian translation is cited for the purposes of this investigations: Alasdaire MacIntyre, Za vrlinom. Studija o teoriji morala (Zagreb: KruZak, 2002, )201; Walter R. Fisher, "Narration, Reason, and Community" in: Lewis P. Hinchman and Sandra K. Hinchman, Memory, Identity, Community, 307-327. 
and to interpret our movements in moral space. (3) the authenticity function: narrative thinking provides us a way of providing concordance to diachronous and synchronous dissonances in our strong evaluation. - Taylor is convinced that among varieties of forms in which strong evaluation can be expressed narrativity is an inescapable form of self-interpretations. Self-interpretations consist not only of our explicit answers to the given questions of "Who am I?", but also of our implicit (ethical) orientation in life - "orientation to the good". 66

\section{On Ricoeur's "Tragic" Narrative ${ }^{67}$}

Ricoeur's theory of narrative identity refers to those kinds of practical identities whose explication takes a form of "emplotted narratives". In Ricoeur's terminology emplotment is exactly that what Aristotle defines as "a plot" or mythos of tragic work. According to Aristotle, tragedy consists of six different elements ${ }^{68}$, and the most important one is "a plot" ${ }^{16}$. Plot is a soul of tragedy. ${ }^{70}$

Since we have outlined the basic concepts of Aristotle's theory of poetry in a part concerning the explanation of the plot, let us look further (1) why Ricoeur took Aristotelian concept of a plot and (2) what he had found to be so interested in understanding human life as a plot? - In the beginning of the second chapter of his massive work Time and Narrative Ricoeur explains why Aristotle's explanation on a plot is a second ${ }^{71}$ center-point of his inquiry. ${ }^{72}$ One of the reasons is that the central notion of this discussion - a concept of "mimetic activity" (i. e. mimesis) begins with explanation of the problematic of "the creative imitation, by means of the plot as of lived temporal experience."73 As many other Aristotelian commentators, Ricoeur also thinks that Aristotle's Poetics is silent about the relationship between poetic activity and temporal experience. And this relationship Ricoeur wants to rebuild in a way that he

66. Charles Taylor, Sources, 33, 41-42, 44, 81.

67. For this discussion I partly borrowed an epistemological scheme of one peculiar study made on Taylor's and Ricoeur's conception of self-interpretations and narrative identity that is brought out by one, to us less known Finish thinker, Arto Laitinen. In his study entitled "Charles Taylor and Paul Ricoeur on Self-Interpretations and Narrative Identity" Laitinen brings out convergences and divergences between Taylor's and Ricoeur's conception according to which narrative is strongly defined by social determinants.

68. These are plot, character, diction, thought, spectacle and melody. Aristotle, Poetics, VI. $1449 \mathrm{~b}$ 1. (Croatian translation of the work is cited here: Aristotel, O pjesničkom umijeću (Zagreb: Školska knjiga, 2005); Ibid., V, 1450 a 10.

69. Aristotle, Poetics, V., 1450 a 35.

70. Ibid.

71. The first one is Augustine theory of time (a. n.).

72. Paul Ricoeur, Time and Narrative: vol 1, 5-31.

73. Ibid. 
takes Aristotelian concept of mimesis interpreted in his own - hermeneutic manner as a mediator between time and narrative..$^{74}$ Many contemporary theorists in the field of social theories, such as Rosemary Huisman in Ricoeurs "concept of threefold mimesis" see(s) a model of way how humans live their life experience. According to Huisman, narratives in any medium or genre are ways of structuring and representing lived experience. ${ }^{75}$ For Arto Laitinen, Ricoeur's threefold mimesis is a way in which identities interpret themselves. Similar to Taylor, Ricoeur also think that, when referring to self-interpretations, the central question is one of particularities of one's self-identity and the answers are provided within culturally and socially mediated self-interpretations. Ricoeurs conception of narrative grounded in philosophical hermeneutics can be applied to the different scientific fields and to practice, too. In linguistic and semiotic, for an instance, threefold mimesis is taken as model of life, of experience that is reachable through all sorts of media: through written texts, picture, soap-opera, film and so forth. In philosophy, as well as in moral theory, mimesis represents the levels of self-interpretation within the space of moral questions that start with a questions Who am I? and Where do I go?, ${ }^{76}$ and continue with interpretations of both interpreter (i. e. Taylor's "moral agent") and interpreted (i. e. Ricoeur's "moral activity"). These interpretations form different stories about humans and their actions which can be judged as moral or non-moral; as unique or plural. People are used to imitate each other in their behavior, and that is something what we inherited from our 'four-legs' predecessors. Life itself is an imitation of varieties of reasonable or failed actions, imitation that has its levels. These levels of imitation Ricoeur calls mimesis1, mimesis2 and mimesis3, but only one is real emplotment or real story (a myth) and that is mimēsis2. Mimessis1 is the reference to the actual world of action to the 'imitated' events that the story is about. This world, according to Arto Laitinen is "pre-narratively organized structurally, symbolically and temporally." The phase of mimessis3 marks the intersection of the world of text and the world of reader. ${ }^{77}$

\section{Ricoeur vs. Aristotle}

In the contrast with Aristotle, Ricoeur thinks that narrative should be characterized not by the author's attitude, but by its object: phenomenology of narrative..$^{78}$ In that sense, Ricoeur distinguishes narrative in the broad sense

74. Text's emphasis is mine.

75. Rosemary Huisman, "The Concept of Narrative" in: Helen Fulton et al, Narrative and Media, 1-27.

76. Text's emphasis is mine.

77. Paul Ricoeur, Time and Narrative: vol. 1, 71.

78. Ibid., 36. 
defined as the "what-form" of mimetic activity and narrative in the narrow sense of the Aristotelian diēgessis ${ }^{79}{ }^{80}$ or in English, story-telling. Although Ricoeur explicitly claims that he does not have any intention to discredit Aristotelian account of mimesis, and he is aware of that Aristotle does not differ mythos from mimesis, and what is evident in his definition of tragedy where he equates mimesis and mythos. Ricoeur, on the other hand, as Arto Laitinen observes, does not equate these two terms. In his opinion, Ricoeur's mimesis contains more than the emplotment, more than the level of mimēsis2 - more than fictional. Mimesis consists of a reference to the world of action (mimēsis1) and to the event of reading (mimēsis3). And that is hermeneutical circle which we may call mimetic circle of the temporal existence. "Time becomes human to the extent that it is articulated through a narrative mode, and narrative attains its full meaning when it becomes a condition of temporal existence." ${ }^{\prime 1}$

\section{Ricoeur's Narrated Identity}

Ricoeur, as well as Taylor holds a stand that our self-identities are marked by strong social and cultural influences. He investigates narrative identity concept from the point of his general analysis of narrativity: narrative as an emplotment and imitation of an action, as I try to explain at previous pages. This investigation applies both to historical and to fictional narratives. According to Ricoeur, there are eight different characterizations of narrative identity (and I will number them according to my explanation of their functions related with personal identity or self): (1) narrative identity contains harmony and dissonance - linguistic position of narrative. (2) narratives are lived and told - biological position of narrative. (3) narrativity includes dialectic of innovation and sedimentation - physiologic position of narrative (4) narratives combine fact and fiction - literal position of narrative. (5) narrative identity mediates between what is? and what ought to be? this is ethical position of narrative. (6) narrative identity mediates between two kinds of permanence in time, between two poles of self-identity: selfhood without support of sameness (pure ipse) and selfhood as supported by sameness (ipse as supported by idem) - ontological position of narrative. (7) theories of narrative identity are located between an affirmation of certain and indubitable " $\mathrm{I}$ " and total rejection of an "I" - psychological position of narrative. (8) in narrative identity the person is not merely the one who tells the story, but he or she appears both as reader and writer of its own life. Thus, the individual is the interpreter and the interpreted, as well as the recipient of the interpretations, hermeneutical

79. Plato speaks on diēgeessis and mimēsis in his Republic. For Plato diēèēsis and mimēsis are the two ways of presenting a story within narrative context.

80. Plato, Republic, III., 5-6; Rosemary Huisman, "The Concept of Narrative" in: Helen Fulton et al., Narrative and Media, 18.

81. Ibid. 
position of narrative.

\section{Convergences and Divergences between Taylor and Ricoeur}

The central difference between the two is that Ricoeur favours indirect hermeneutics whereas Taylor seems to opt for direct hermeneutics. Ricoeur pays more attention on the notion of narrativity in technical sense, unlikely Taylor who does not. The center of Taylor's analysis is a thought or theme of the narrative, while Ricoeur stresses the notion of the plot. Taylor is interested in thematic unity of the life or the sense of direction, better say, and "an orientation" in human life. This orientation is defined by one's ethical choices of our fundamental goals and our sense of being closer to, or further to achieve them. Taylor connects narratives with idea of humans inevitably oriented in their lives towards strong evaluation. For Taylor, as I said before, narrativity is inescapable form of self-interpretations. In other words, as I already mentioned in Summary, people grasp their life in a narrative. In this context, narrative is used as a synonym for story. For Ricoeur on the other hand, story describes "sequences of actions and experiences done or undergone by certain number of people, weather real or imaginary." 82 This 'sketch' of the notion of story is very close to what Ricoeur calls emplotment. Further on, for Ricoeur making the story includes both organization of events into a story with a plot (mythos) and an imitation of an action (mimesis). The main role here belongs not to the writer but to the reader who reads a story. To read a story, pragmatically, means to follow thoughts and feelings that are expressed in it. In that sense, I shall appeal to Taylor's claim: if we want to understand one's life story, we have to make a turn of 180 degrease towards story of another one. In other words, to understand another human being asks for our understanding of his or her (personal) life-story, as well as cultural and social milieu and tradition to which he or she belongs to. But, above all, most important think that we have to understand here, if we want to live our life meaningfully: as wholeness (Taylor), or to conduct business etc., we are called upon to find a way of how we can - let me use a jargon - 'keep hanging together' in the age that still cries for its authentic way of expressing identity which is determined by the two extremes already defined by Pascal: misère and grandeur. These epistemological challenges Taylor describes in his The Ethics of Authenticity: extreme individualism - at private level; instrumental reason - at social and business level and loss of freedom - at political level. ${ }^{83}$ All of three above-mentioned characterizations sometimes appear as a scar on the face of modern identity, or as a barrier to the "followability" 84 of one's life-story.

82. Paul Ricoeur, Time and Narrative: vol. 1, 150.

83. Charles Taylor, The Ethics of Authenticity, chap. 1.

84. Ricoeur's term. 


\section{iPhone: from Story-Telling Form to Emplotted Digital}

Human life or "lived experience" - Ricoeur's term for what Taylor defines as a life-story, "a plot" is always in action. This action has duration and what depending on Aristotle's causa efficiens: a man. A man is at the same time both main actor or character, writer and story-teller of his or her own play: one's personal life. A life that depends on many circumstances involved with it that is ontological perspective. But, mostly depends on organization of all features that create, modify and represent one's life - that is economic perspective. These features we may define as mediatory links between 'how it is?' and 'how it should be?'; real and virtual; real and ideal; economical and ethical. As narratively constructed features our identities are determined by both real and fictional: two modes of our temporal existence. Real and fictional are intertwined in individual digital: in iPhone.

In other words, not just that each of us live in a certain type of digital story - or Steve Jobs's i-Phone app(s) - which might be considered as a form of narrative, too, but people live their stories in their peculiar apps-way: engaged with different sources of fictional (i. e.) virtual reality defined by one's app/s choice. People live their stories following some rules that are prescribed by some social or cultural milieu. But, mostly they live their story in particular way, interpreting and evaluating characters (e. g. Facebook), times (e. g. Viber of Whatsapp) and places (e. g. Instagram), as well, as their manners and forms are judged throughout representative's oneself tool (e. g. gadget or any social net or app); 'who we are?' (identity), where're we standing (Taylor's spatial orientation) and where're we going (temporal dimension). That is what narrative is: an expressive time-spaced determinant of human existence. And for this existential phenomenon I have found 'a perfect' name. Being motivated by Nikola Tesla I shall call it 'an ontological ether', weather we speak of private or social (business) life, and the boundaries of this existential ether depend on the form and disposition between the elements (i. e. gadgets' apps) which form mediatory links between interlocutors (i. e. a man and iPhone) within the process of narration, ${ }^{85}$ which ${ }^{86}$, in addition, we choose according to our preferences, or economic and social standard.

Speaking of Jobs's $i$-Phone, I am assured that the standard is defined by hidden request for disposing "the inner man". What I want to say is that $i$ Phone, beyond all economic calculations dictated by global trade market policy, is a digital demonstration of one's inner narrative. This " $\mathrm{I}$ " within the term $i$-Phone aiming showing one's authenticity, a personal identity in a way that everyone can choose for him- or herself the perfect order of using certain app(s) with specific function of it.

85. In this process $i$ Phone took over the role of digital interlocutor.

86. Refers to the hardware and software system of certain iPhone model. 
My aim was to connect the narrative concept with an $i$-Phone phenomenon. As I see it, iPhone is digital construction of one's personal identity. Partly, this is something what I have been doing with my undergraduate and graduate students at Business Ethics course class every year in fall semester since 2009. But, above all, this is something worth of investigation, at least in a part referring to Philosophy of Digital. The point is that we have to find a way how to distribute an authentic idea when authenticity is priceless! Or how to turn authentic idea into something real in an age where we are flooded with all kinds of goods and services? What else can we invent and without already being invented? And what about the iPhone-phenomenon: whether the iPhone represents the beginning, the highlight or the end of era of technological advancements?! - Aristotle would probably say that all lies in our power of imagination. Taylor has found 'a perfect' term that connects our ideas with the capacity of expression of them: "visual metaphors" 87.

At the same time humans are inhabitants of the two-parallel worlds ${ }^{88}$ : a fictional or inner one and real or digital one. And both worlds create what Ricoeur defines as "emplotted" life: weather life of pure thoughts or of performed thoughts or digital. And, in the world dominated ${ }^{89}$ by $i$-Phone a digital is perfect example of the living emplotment.

Is Steve Jobs's i-Phone 2007 an offshoot of mimesis (Aristotle and Ricoeur) or a story-telling (Ch. Taylor)? - My answer on the given question is that iPhone involves both. As a highlight of 21th c. high-tech industry, and according to Heidegger's explanation of what I have called "a thinking hand", I would say that iPhone performs just a mimetic activity dictated by one's finger. But, on the other hand, as computing memory, iPhone is immense and all information we put on the iPhone's memory can be transited into collective identity - an iCloud - something that resembles Jung's "collective conscience".

How one's iPhone is organized can tell us much about a person, so I would say that iPhone is an off-shoot of storytelling - in that case. iPhone, undoubtedly, represents a virtual space of our inner life: our schedules, notes, calls, textmessages, e-males, contacts, app stores, reminders, videos and pictures. Simply, it represents our whole life in digital form for which we need a finger (or "digitus") only - to start it over again.

87. Charles Taylor, Human Agency and Language. Philosophical Papers 1, 257.

88. I use a term strictly in colloquial sense.

89. Statistics of how many of iPhones has Apple Inc. sold out since October 2007: "Global Apple iPhone sales from 3rd quarter 2007 to 4th quarter 2018 (in million units)," Statista, https://bit.ly/2LBEW1f, accessed 18 February 2019. 


\section{Instead of Conclusion}

I will use Aristotelian classic syllogism in order to depict connection between Jobs's iPhone, Ch. Taylor's narrated identity and P. Ricoeur's temporal mimetic reality, whereas human behavior is strongly determined by the way of how we use or don't use high technologies today for personal and social purposes, and in that sense iPhone represents revolution because it is designed according to one's authentic needs and deeds and what - in practice coincides with theoretical position describes in Charles Taylor philosophical critique of modernity designated by radical individualism - so called "individualism of self-fulfillment" ${ }^{90}$ Analogically, we might claim that Jobs's iPhone is allegory for one's radical turn towards inner self (i. e. personal identity or self); towards that " $\mathrm{i}$ " in an iPhone phonetical order of a term. In the other hand, the way we use modern technologies applied to Jobs's iPhone depends on that of how our life in general looks like; on the stage of Ricoeur's mimetic activities. We might think of that stage as of 'time-spaced capsule ${ }^{\prime 91}$ Tesla's "Ether", whereas our deeds, desires, thoughts circulate back and forth and what depends on the intensity and status of the good in our life. This mimetic action in which one might be at the same time both designer of his or her life-story and story-teller belongs to the mimetic level 2 or "mimesis2": mimetic action + occurrence assimilated in "mimesis3": mimetic action + plot (occurrence) + reader (mediator of threefold action) $=$ human behavior (see Table 1).

\begin{tabular}{|l|c|}
\hline Premise 1: & narrative + identity $=$ human being (i. e. moral agent) \\
\hline Premise 2: & identity $=$ self-interpretation + moral space \\
\hline Premise 3: & : moral space + moral agent $=$ temporal dimension \\
\hline Conclusion 1: & temporal dimension + action $=$ mimesis \\
\hline Conclusion 2: & mimesis + life $=$ story-telling \\
\hline The closure: & i-Phone $=$ mimesis + story-telling \\
\hline
\end{tabular}

Table 1. Philosophizing an iPhone schematic view. ${ }^{92}$

We might say that people are by their very nature the dreamers ${ }^{93}$. They dream on things, other people, places and events by which they are surrounded and hence, determined in their life environment - "the Ether". Their dreams are crucial part of their life that can be expressed in written, oral or in visual modes of expressions, but in the age we live our dreams are usually expressed in digital modes.

90. Charles Taylor, The Ethics of Authenticity, 2.

91. My neologism.

92. Sources: the author's scheme.

93. I use a term in psychological, Jung's term. 
Why did we use the term dream as main characterization of human nature in our investigations of philosophizing the iPhone? - The answer is very simply. We live in the age dominated by different sorts of digital modes that shape our life as well as our personal identities: communicative digital: smart phones, social nets like Instagram, Facebook, Twitter, YouTube are app/s designed on one's smart phone display.

How does digital shape our identities? - Digital shapes our identities by designing an invisible matrix form in which we are caught in due to high-tech and digital communicative space, in a way that individuals might not always be aware of what is happening. For an instance, when he or she enjoys watching some movie, or serial, or jeopardy, or reading some interesting novel, or listening to some radio station or watching YouTube source, they become integrated in the very source of certain digital space: one's smart phone screen that represents one's whole life displayed within 4 (iPhone SE) or 4.7 inches (iPhone 6s) or 5,5 inches (iPhone 6s plus). (See figure 3.)

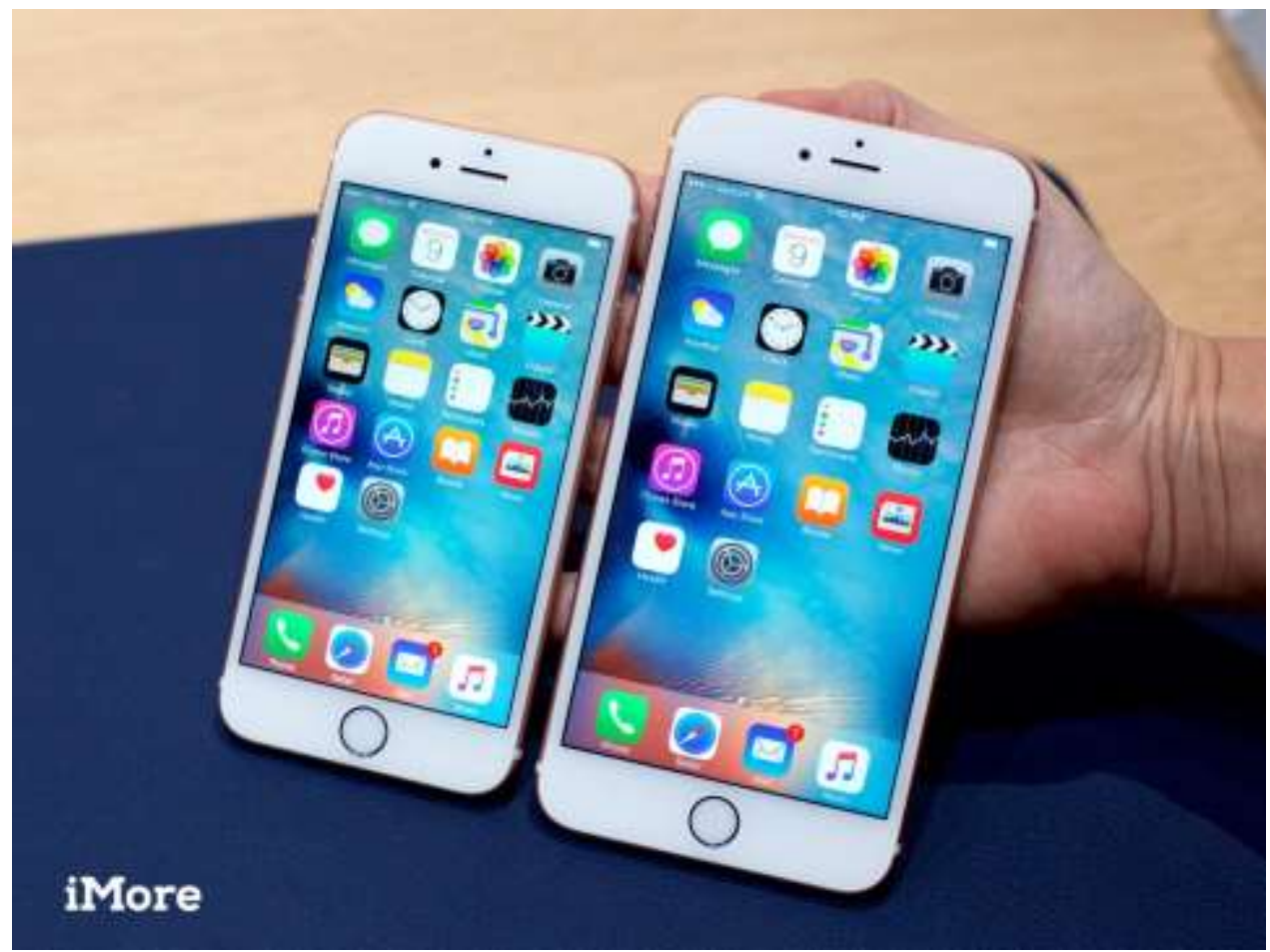

Figure 3. iPhone's Display Size

Source: https://bit.ly/2LqaxCQ.

\section{Acknowledgments}

Part of the paper regarding an iPhone phenomenon was presented and rewarded at ABSRC Venice 2018 Conference in Italy. The core part of this elaboration concerning the concept of narrative within Charles Taylor and Paul 
Ricoeur philosophical thought was originally made and presented under the title "Understanding of Narrative in Media" at Philosophy and Media international conference held in autumn 2009 on the island of Cres - Croatia. My thanks to ATINER's 'stuff' for academic cooperation. I thank to my life-time students at home and abroad with whom I share my love of Steve Jobs' and his inventive mind. And I must admit that many diploma works written under my mentorship between 2010 onwards are in great per centage written about Steve Jobs and philosophy of Apple Inc. Hoping that Apple Inc. will forgive me for I did not 'install' the photo of the newest version of the iPhone 11 !

\section{Bibliography}

AAVV. Communication Today. Trnava: Faculty of Mass Media Communication University of SS Cyril and Methodius, 2 (2016).

Abbey, Ruth. Charles Taylor. Acumen: Acumen Publishing Ltd., 2000.

Apple Inc. Official web-side. https://www.apple.com/.

Aristotle. Poetics/O pjesničkom umijeću, Zagreb: Školska knjiga, 2005. Croatian translation.

Dunne, John S. Time and Myth. Notre Dame and London: University of Notre Dame Press, 1975.

Fulton, Helen, et al. Narrative and Media. Cambridge: Cambridge University Press, 2005.

"Global Apple iPhone sales from 3rd quarter 2007 to 4th quarter 2018 (in million units)." Statista. https://bit.ly/2LBEW1f. Accessed 18 February 2019.

Heidegger, Martin. Being and Time. Various editions, 1927.

. Bitak i vrijeme. Zagreb: Naprijed, 1988. [Croatian translation].

Hinchman, Lewis P. and Hinchman, Sandra K. ed., Memory, Identity, Community. The Idea of Narrative in the Human Sciences. New York: State University of New York Press, 2001. 1997.

Laitinen, Arto. Charles Taylor and Paul Ricoeur on Self-Interpretations and Narrative Identity. https://bit.ly/3buoA4X.

MacIntyre Alasdair. After Virtue. Notre Dame, Ind.: Notre Dame Press, 1981.

Nietzsche, Friedrich. Beyond Good and Evil/Niče, Fridrih. S one strane dobra i zla. Beograd: Grafos, 1980.

Plato, Republic/Država. Zagreb: Matica hrvatska, 1941. [Croatian translation].

Ricoeur, Paul. Time and Narrative: vol. 1. Chicago and London: The University of Chicago Press, 1983.

Scholes, Robert, Phelan, James and Kellogg, Robert. The Nature of Narrative. Oxford University Press, 1996.

Sherman, W. R., and Craig, A. B. Understanding virtual reality: Interface, application, and design. Morgan Kaufmann, 2018.

Taylor, Charles. Human Agency and Language. Philosophical Papers 1. Cambridge: Cambridge University Press, 1985.

Taylor, Charles. Sources of the Self. The Making of the Modern Identity. Cambridge - Mass.: Harvard University Press, 1989. 
Vol. 7, No. $3 \quad$ Vidanec: Philosophizing the Jobs's iPhone within Philospohical...

Taylor, Charles. The Ethics of Authenticity. Cambridge, Massachusetts and London, England: Harvard University Press 1991/112003. [Croatian translation: Etika autentičnosti]. Split: Verbum, 2009.

Taylor, Charles. A Secular Age. Harvard University Press, 2007.

Tesla, Nikola. "Was Nikola Tesla right about his ether theory?" Physics. https://bit.ly/2YZP Fug. Accessed 12 April 122020.

VB Transform 2020. https://bit.ly/3bvLzMO. 